\title{
Public Infrastructure Provision in Bauchi Metropolis, Nigeria
}

\author{
Ibrahim Idris ${ }^{1}$, Samirah Ibrahim Jibril ${ }^{1}$, Hadiza Tijjani Bello ${ }^{1}$, Muhammad Usman Adekunle ${ }^{1}$ \\ ${ }^{1}$ Abubakar Tafawa Balewa University \\ Tafawa Balewa Way, P. M. B. 0248, Bauchi, 740272, Nigeria
}

DOI: $10.22178 /$ pos.62-1

JEL Classification: H54

Received 19.08.2020

Accepted 25.09.2020

Published online 30.09.2020

Corresponding Author:

Ibrahim Idris

ibrmidris@gmail.com

(C) 2020 The Authors. This article

is licensed under a Creative Commons

Attribution 4.0 License @ (1)

\begin{abstract}
This study aims to assess the Public infrastructure provision in Bauchi Metropolis, Nigeria, to propose areas of improvement. The study adopted the use of a quantitative approach and data were collected through a questionnaire survey from 382 house head holds proportionate selected from the target population in Bauchi metropolis. The data collected were subjected to descriptive with mean ranking, frequency distribution. The study revealed that communication facilities were the most provided facility provision, followed by market facilities and water facilities provision. Solid waste disposal facilities and fire protection services were the least facilities provided in the study area. It recommended that public infrastructural facilities provided in the area should be based on the resident's preference and need.
\end{abstract}

Keywords: Infrastructure; Provision; Facilities; Services; Preference; Residents.

\section{INTRODUCTION}

The state of infrastructure is an essential parameter of assessment and indicator of any urban classification [12]. The efficiency of any type of human activity system, including the urban area, largely depends on the provision of efficient infrastructure and services considering residents' preference [3]. The significance of infrastructure in the proper execution of an urban area cannot be overemphasized. Urban infrastructure apart from being a major pointer of environmental quality is a critical agent for the socio-economic development of an urban area [9].

Like any other nation in the world, Nigeria has its stock of urban infrastructure provision. Included in this stock are electricity, water, road, communication, drainage, waste disposal educational facilities, health care facilities, recreational facilities, and security and fire service facilities [8]. The federal, state and local governments in Nigeria are often involved in the provision of facilities and services in major urban centers [8].

The level of availability of public infrastructural facilities provided in accordance to residents' preference in most developing countries is alarmingly low even though the quality and coverage of these infrastructural services provision have a major impact on living standard and economic prosperity of people and the efforts made in tackling the situation, the problem is escalating [5].

This assertion is evident from World Health Organisation [16] report that estimated that about 2 billion world poor people lack access to adequate sanitation and 2 billion lack access to electricity while another 1 billion lack access to clean water.

\section{Literature review}

Infrastructure can be defined as the system of services, utilities, and facilities that provide for the basic wellbeing and superiority of life [17]. Therefore, the term infrastructure refers to the practical structures that enhance living conditions in any civilization which includes health facilities, agricultural facilities good roads network and telecommunications as well as energy and water supply.

Infrastructure was defined by [2] as the basic physical and organizational structure needed for the operation of a society or enterprise, or the services and facilities necessary for an economy to function. Viewed functionally, infrastructure facilitates the production of goods and facilities, and also the distribution of finished houses to markets, as well as basic social services such as 
schools and hospitals; for example, roads enable the transport of raw materials to a factory and also the distribution of finished houses to markets or the services and facilities necessary for an economy to function. The author [8] describes infrastructure as the aggregates of all facilities that allow a city to function effectively.

It is also seen as a wide range of economic and social facilities that help in creating an enabling environment for economic growth and quality of life. The author [11] also thought that infrastructure services have a bearing on economic growth. Similarly, the author [15] shared the same view by stating that infrastructure refers to all basic inputs and requirements for the proper functioning of the economy. Infrastructure is simply the engine that is needed for the proper functioning of a city. It can be put in place by private or public involvement to facilitate the effective functioning of the society and also infrastructure categorized into two namely physical and social infrastructures. Infrastructural facilities provision refers to those basic services without which primary, secondary, and tertiary productive activities cannot function. In its wider sense, it embraces all public services from law and order through education and public health to transportation, communications, and water supply [7].

The author [6] divided rural facilities in Nigeria into three main groups; namely, physical (transportation, storage, processing, water resources), social (health, education, utilities), and institutional (cooperative societies, financial institutions, agricultural research and training, and house marketing) infrastructures. Infrastructural facilities provision includes electricity, police station, silos, post offices and agencies, markets, motor parks, hospitals, primary healthcare centers, banks, primary and secondary schools, and town halls.

Authors [17], further described infrastructure as facilities and basic systems on which the sustainability and growth of a community and state depend. This means that infrastructure is an essential ingredient for the smooth function of any economy and development of any nation. According to the structuralist/functionalist theorists, the progress or otherwise of a society depends largely on the functional structures of that society. What this means is that structures in the societies will largely determine the economic development. To [9], infrastructure is made up of public utilities such as power, pipe-borne water supply, telecommunications, sanitation and sewage, solid waste collection and disposal, piped gas, while public works include roads, major dams, canal works for irrigation, and drainage. More infrastructures are in the transport sector, such as urban into urban railways, urban transport, waterways, and airports.

The characteristics of infrastructural facilities are heavy capital outlay for investment, the invisible, low variable cost, and long gestation period. The author [13] provides an extensive overview of the definition of infrastructure and define infrastructure as a capital good (provided in large units) in the sense that it is originated by investment expenditure and characterized by long duration, technical indivisibility.

Economic Infrastructure provision. Is seen at a particular point in time, as a division of an economy's capital stock used to ease economic production, or serve as inputs to production (E.g. electricity, road, and ports). This helps to produce things that are consumed by households (e.g. water, sanitation, and electricity). Economic infrastructure can further be subdivided into three categories: utilities (power, piped gas, telecommunications, water and sanitation, sewerage and solid waste disposal), public works (roads and water catchments in dams, irrigation, and drainage), and other transport sub-sectors (railways, waterways and seaports, airports and urban transport systems).

In national accounts data, these are found in two sub-headings of the gross domestic product (GDP): electricity, gas, and water are located in the Secondary sector; while transport, storage and communication are found in the Tertiary sector [16].

Social Infrastructure provision. Encompasses services such as health, education, and recreation; it has both direct and indirect contact on the quality of life. Directly, it enhances the level of productivity in economic activities, indirectly, it streamlines actions and outcomes such as recreation, education, health, and safety. The indirect benefit of enhanced primary health care, for example, is improved productivity, which in turn leads to higher economic growth and real incomes [16].

Also, some infrastructure ventures give benefits past the envisioned direct advantage: for instance, a road enables community member to travel more easily, expands the travel industry to the nation since sightseers can all the more effectively travel, or may build training utilization since children 
would now be able to go to school more easily, .road infrastructure then again is the structural facilities that guide the movement of people and products through the different methods for transport on road It is said to be composed of the following: The carriageway; the pedestrian facilities (where applicable), Drainage system, Culverts (Box or Ring types), Bridges and flyovers, Street light installations, Traffic signs, Traffic Islands, etc, [1].

\section{Methodology}

The study adopted the use of exploratory and descriptive design to uncover facts about its background and problems. This research was carried out in the Bauchi metropolis which is the capital city of Bauchi State. There are twenty (20) wards in Bauchi Local Government Area, with a household population of 136, 735 [4].

The study covers the provision of public infrastructural facilities such as water facilities, electricity facilities, road accessibility, drainages, and waste disposal, schools, hospitals, market, security, and communication. The eight (8) wards are Dan Amar A \& B, Dan Iya, Dankade, Dawaki, Hardo, Makama A \& B. The target respondents for this study are household heads living in each of the eight (8) wards.

The sample frame is the total number of items for the study population. As Bauchi metropolis comprised of eight (8) administrative wards (Table 1), the sample frame of this study is the total household heads in the eight (8) wards $(75,177)$ as stated by [4].

\section{Table 1 - Sample Frame \& Sample Size}

\begin{tabular}{|l|l|l|l|}
\hline No & \multicolumn{1}{|c|}{ Wards } & $\begin{array}{c}\text { Households } \\
\text { (sample frame) }\end{array}$ & Sample size \\
\hline 1 & Dan Amar A & 8,758 & 45 \\
\hline 2 & Dan Amar B & 12,931 & 66 \\
\hline 3 & Daniya & 10,365 & 53 \\
\hline 4 & Dan Kade & 6852 & 35 \\
\hline 5 & Dawaki & 13316 & 67 \\
\hline 6 & Hardo & 3674 & 19 \\
\hline 7 & Makama A & 9496 & 48 \\
\hline 8 & Makama B & 9785 & 49 \\
\hline & TOTAL & 75,177 & 382 \\
\hline
\end{tabular}

Source: [4]

This study used structured questionnaires to generate quantitative data from the respondents.
Statistical Package for Social Science (SPSS, version 22) was used for statistical analysis of the data generated from the questionnaire survey. The data obtained using the questionnaire survey was thoroughly screened, analyzed, and sorted out for analysis depicting the information responses from the respondent, as the study contained descriptive research questions, mean ranking was used.

Descriptive statistics based on the mean ranking was carried out to assess the level of public infrastructure provision in Bauchi metropolis, Nigeria.

\section{RESULTS}

The results showed the ranking, mean standard deviation, and remark for each item. Table 2 shows the level of provision of public infrastructural facilities in the Bauchi metropolis.

Table 2 - Provision of Public Infrastructure

\begin{tabular}{|l|l|l|l|l|}
\hline Infrastructures & Mean & $\begin{array}{c}\text { Std. } \\
\text { Deviation }\end{array}$ & Rank & Remark \\
\hline Communication & 3.08 & 1.30 & 1 & Moderate \\
\hline Market & 3.05 & 1.36 & 2 & Moderate \\
\hline Water & 2.91 & 1.31 & 3 & Moderate \\
\hline Education & 2.86 & 1.22 & 4 & Moderate \\
\hline Security & 2.86 & 1.36 & 5 & Moderate \\
\hline Road & 2.77 & 1.32 & 6 & Moderate \\
\hline Health & 2.70 & 1.19 & 7 & Moderate \\
\hline Landscaping & 2.60 & 1.23 & 8 & Low \\
\hline Drainage & 2.56 & 1.29 & 9 & Low \\
\hline Recreational & 2.56 & 1.22 & 10 & Low \\
\hline Electricity & 2.53 & 1.23 & 11 & Low \\
\hline $\begin{array}{l}\text { Solid waste } \\
\text { disposal }\end{array}$ & 2.41 & 1.17 & 12 & Low \\
\hline Fire service & 2.23 & 1.28 & 13 & Low \\
\hline
\end{tabular}

It shows that the infrastructural facilities that were provided most, based on five-point measurement scale, were communication service facilities with 3.0800 mean ranked 1st, market facilities with 3.0533 mean ranked 2 nd, water facilities of 2.9167 mean ranked 3rd, education facilities with mean values of 2.8633 ranked 4 th, security facilities with mean value of 2.8600 ranked 5th, road facilities with mean value of 2.7700 ranked 6th, health facilities with mean value 2.7033 ranked the 7 th and were moderate in provision level, environmental landscaping facilities with mean of 2.6033 ranked the 8th, drainage facilities with mean value 2.5667 ranked the 9th, neighborhood recreational facilities with mean value of 
2.5633 ranked the 10 th, electricity facilities with mean value of 2.5333 ranked the 11 th, solid waste disposal with value of mean 2.4167 ranked the 12th and the least provided infrastructures in the study area was fire service facilities with mean value of 2.233 in the table above and were low in provision level. Therefore, these results were indicating moderate and low infrastructural facilities provided in the study area.

The findings from the mean ranking of the thirteen (13) public infrastructural facilities provision in construct on infrastructure provision showed that communication facilities were the most provided facility provision, followed by the market facility and water facility provision. Electricity facility, solid waste disposal facility, and fire protection services were the least provided facilities.

It also showed the inefficiency in the provision of electricity facility, solid waste disposal, and fire protection services. The inadequacy of facilities provision in Nigerian cities can be traced back to the 1990 when there was a breakdown in the infrastructural provision system [17]. This was a result of underfunding, which resulted in the inability of infrastructural development to keep face with facility provision. To accomplish the sub-objectives of preparing residents to live viably in the period of science and technology, the act of starving the town and city from infrastructural facilities provision and services equipment and underfunding need to change.

\section{CONCLUSION}

The study aims to assess the Public infrastructure provision in Bauchi Metropolis, Nigeria to recommend possible areas of improvement.

The findings from the survey carried out indicated that the provision of a communication facility, market facility, water, education, and security was the most effectively provided in the study area.

The research recommended that effective policy implementation to address the problems of inadequate infrastructural facilities provision. Inadequate infrastructural facilities provision hurts resident satisfaction and willingness to stay in the area, such problems can be solved by increasing the number of infrastructural facilities such as communication facilities and electricity facilities to residents. Increase road facilities can ease movement for the residents.

The study also recommended that adequate infrastructural facilities provision enhance the social and economic function of the residents.

\section{REFERENCES}

1. Abdulkareem, S., Ali Khan, A., \& Konneh, M. (2010). Cooling Effect on Electrode and Process Parameters in EDM. Materials and Manufacturing Processes, 25(6), 462-466. doi: $10.1080 / 15394450902996619$

2. Adebimpe, O. A. (2016). The Impact of Infrastructural Facilities on Residential Property Development in Ota, Ogun State Nigeria. Covenant Journal of Research in the Built Environment, $3(2), 1-12$

3. Babarinde, J. A. (1998). Analysis of Industrial relocation in relation to Housing and Infrastructural services in Metropolitan Lagos. The Lagos Journal of Environmental studies, 1(1), 97-108.

4. Bauchi Local Government. (2016). Immunisation data. Bauchi Local Government.

5. Ibem, E. O. (2011). The contribution of Public-Private Partnerships (PPPs) to improving accessibility of low-income earners to housing in southern Nigeria. Journal of Housing and the Built Environment, 26(2), 201-217. doi: 10.1007/s10901-011-9213-1

6. Idachaba, F. S. (1985). Rural infrastructures in Nigeria. Ibadan: Ibadan University Press.

7. Mabogunje, A. (2001). Abuja: the provision, the performance and the prospects. The review of Abuja master plan (pp. 1-10). Ibadan: Fountain publications.

8. Nubi, T. 0. (2002). Procuring, Managing and Financing Urban Infrastructure: Towards Integrated Approach Paper presented at a National Workshop on Land Management and Property Tax Reform in Nigeria. Organized by Estate Management Department, University of Lagos, Akoka. 
9. Okusipe, M. O. (1999). Environmental quality and urban planning: A case of Metropolitan Lagos, Nigeria. The Lagos Journal of Environmental Studies, 2(1), 53-63.

10. Omagu, F. E. (2016). Infrastructural development in Nigeria: a panacea for transforming educational sector for sustainable national development. International Journal of Capacity Building in Education and Management, 3(1), 13-19.

11. Selwyn, N. (2004). Reconsidering Political and Popular Understandings of the Digital Divide. New Media \& Society, 6(3), 341-362. doi: 10.1177/1461444804042519

12. Singh, R. K., Murty, H. R., Gupta, S. K., \& Dikshit, A. K. (2012). An overview of sustainability assessment methodologies. Ecological Indicators, 15(1), 281-299. doi: 10.1016/j.ecolind.2011.01.007

13. Torrisi, G. (2009). Public infrastructure: definition, classification and measurement issues. Retrieved from https://mpra.ub.uni-muenchen.de/12990/1/MPRA_paper_12990.pdf

14. Weissberger, G. H., Goodman, M. C., Mosqueda, L., Schoen, J., Nguyen, A. L., Wilber, K. H., ... Han, S. D. (2019). Elder Abuse Characteristics Based on Calls to the National Center on Elder Abuse Resource Line. Journal of Applied Gerontology, 39(10), 1078-1087. doi: $10.1177 / 0733464819865685$

15. Wolters, T. J. (2002). Predictive monitoring and problem identification in an information technology (IT) infrastructure. Patent 7107339. Retrieved from https://patents.justia.com/patent/7107339

16. World Health Organization, \& UNICEF. (2014). Progress on sanitation and drinking water: 2015 Update. Retrieved from https://www.unicef.org/publications/index_82419.html

17. Ziara, M. \& Ayyub, B. (1996). Methodology for construction reduced-cost Housing: System framework with decision analysis. Birzeit. 